\title{
Distribution, density and specific composition of water mites (Acari) in the sublittoral of Lake Banyoles (Spain)
}

\author{
M. Rieradevall ${ }^{1}$ \\ M.J. Gil2
}

Keywords : sublittoral population, water mites, karstic lakes, lake Banyoles.

The seasonal and bathymetric occurrence of water mites in the sublittoral and profundal zones of lake Banyoles were studied in 1986-1987. Four species were found in the mud substrate : Neumania deltoides (Piersig, 1894), Neumania imitata Koenike, 1908, Unionicola crassipes (Müller, 1776) and Arrenurus sinuator (Müller, 1776). The maximum depth that water mites reached was $12 \mathrm{~m}$, but they were more frequent and abundant at $5 \mathrm{~m}$ depth, mainly in the March-May period (41 individuals per $\mathrm{m}^{2}$ ). This group represents only $0.08-0.39 \%$ of the total macrobenthic fauna in the sublittoral of lake Banyoles. $N$. deltoides is the most abundant and widely distributed species. For $N$. imitata this is the first record in the Iberian peninsula.

Distribution, densité et composition spécifique des Hydracariens (Acari) dans la zone sublittorale du lac de Banyoles (Espagne)

Mots clés : population sublittorale, hydracariens, lacs karstiques, lac Banyoles.

La distribution bathymétrique et saisonnière des Hydracariens des zones profonde et sublittorale du lac de Banyoles a été étudiée en 1986-1987. Quatre espèces ont été trouvées dans le substrat vaseux : Neumania deltoides (Piersig, 1894), Neumania imitata Koenike, 1908, Unionicola crassipes (Müller, 1776) et Arrenurus sinuator (Müller, 1776).

Les Hydracariens atteignent une profondeur maximum de $12 \mathrm{~m}$, mais sont le plus abondants à - $5 \mathrm{~m}$, surtout entre mars et mai (41 ind $\left./ \mathrm{m}^{2}\right)$. Ils ne représentent cependant que 0,08-0,39 \% de la faune macrobenthique totale de la zone sublittorale du lac. $N$. deltoides est l'espèce la plus abondante et la plus répandue. Il s'agit de la première citation de $N$. imitata pour la péninsule ibérique.

\section{Introduction}

The importance of water mites is well known, firstly as ectoparasites of different insects, mussels and sponges (Prasad \& Cook 1972, Böttger 1976) and secondly as predators of larvae of insects, or on microbenthic organisms such as cladocera, ostracoda or nematoda (Böttger 1970, Gledhill 1985, Ten Winkel 1987). This incidence, at two levels, on the benthic community population reveals the water mites as a very interesting group. Water mite communities in littoral zones have been largely studied, due to the high diversity and abundance of individuals, but not very much attention has been paid

1. Dep. Ecologia, University of Barcelona, Diagonal 645, 08028 Barcelona, Spain.

2. Dep. Didáctica Ciencias Experimentales, University of Zaragoza, San Juan Bosco n 7, 5009 Zaragoza, Spain. to deeper communities in benthos studies, where water mites have generally been identified only as a group. This study is a part of a project on the ecology and dynamics of zoobenthos of sublittoral and profundal zones in lake Banyoles (Rieradevall 1991). The aim of this paper is to present data on the specific composition, distribution and densities of water mites in different parts of this karstic lake.

\section{General features of Lake Banyoles}

Geographically, lake Banyoles is situated at $42^{\circ} 7^{\prime} \mathrm{N}, 21^{\circ} 45^{\prime} \mathrm{E}$ and $175 \mathrm{~m}$ above sea level. Maximum length is $2.130 \mathrm{~m}$ and its surface area is $1.18 \mathrm{Km}^{2}$. The lake is the biggest water mass of a karstic system, which includes several accompanying ponds, and the main entrance of water is by means of subterranean inflow. As a result of deep water inflow, permanent suspended sediment is maintained 
in some deep parts of the lake and ponds. Mean depth is $15 \mathrm{~m}$ and maximum depth is $35-40 \mathrm{~m}$ over suspended sediments. The littoral zone (0-3 m) represents a thin strip, since the lake rapidly reaches a depth of 2-3 m. Macrophytic vegetation (Phragmites, Schoenoplectus, etc.) and several Myriophyllum verticillatum meadows and travertinic rocks are abundant.

Secchi disk depth ranged between 0.9 and $6.8 \mathrm{~m}$, in the $1986-87$ period. Bottom temperatures varied between $8^{\circ} \mathrm{C}$ and $18-25^{\circ} \mathrm{C}$ depending on depth (Table 1). The water was rich in calcium and sulphate (Planas 1973). Conductivity and $\mathrm{pH}$ of surface water was around 1,300 $\mu \mathrm{S} . \mathrm{cm}^{-1}$ and 7-8.15 respectively. The bathymetry of the lake reveals five main basins (Fig. 1), with different limnological behaviour along the year. That is, the period with anoxic hypolimnetic waters varies between one, four and twelve months in basins I, IV and III, respectively, for the same stratification period (Table 1).

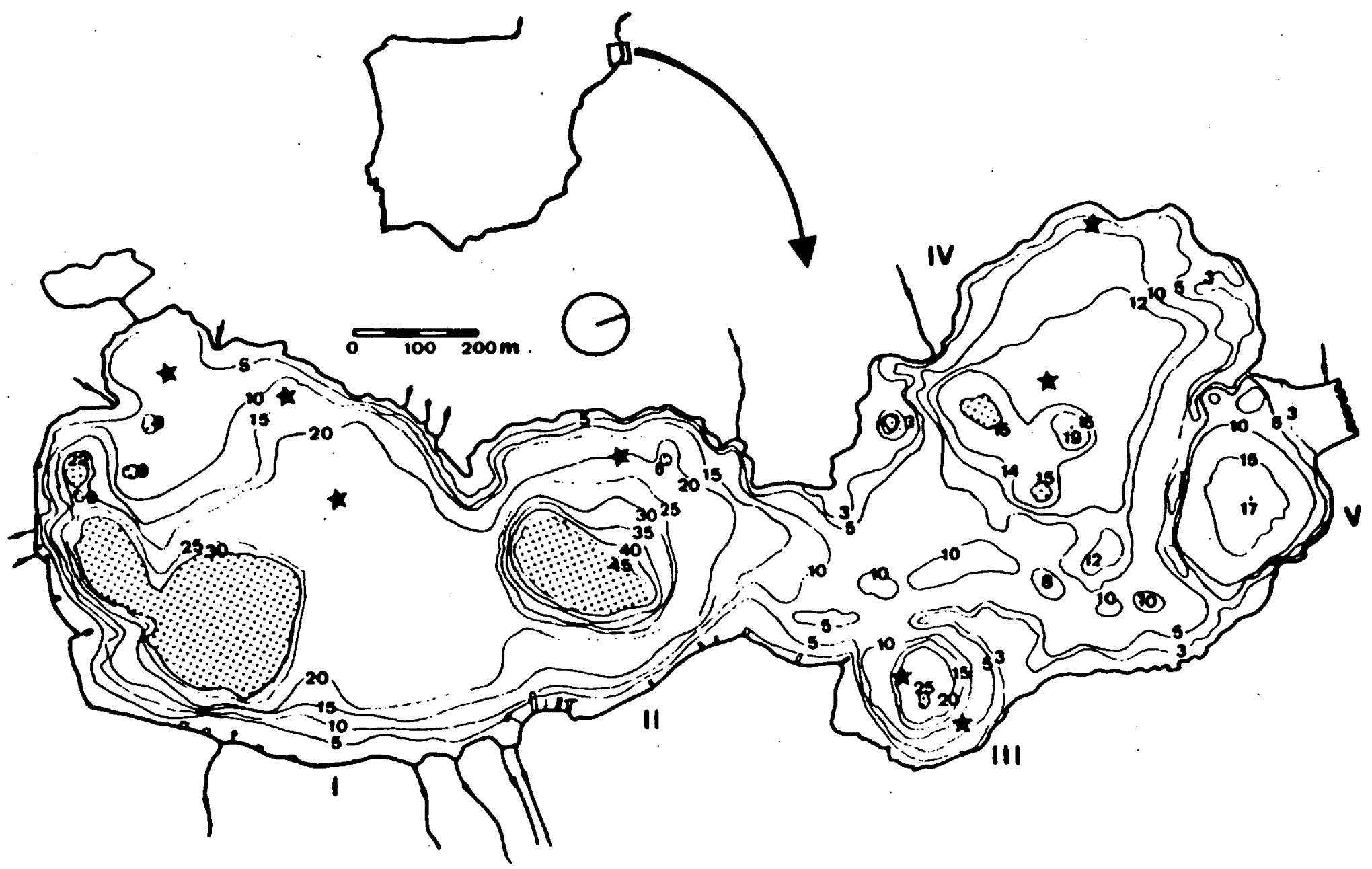

Fig. 1. Bathymetric map of lake Banyoles showing the situation of the sampling stations (stars) in basins I, II, III and IV.

Fig. 1. Carte bathymétrique du lac de Banyoles montrant la situation des stations étudiées (étoiles) dans les bassins I, II, III et IV.

Table 1. Minimum and maximum values of bottom temperatures and dissolved oxygen concentrations at each sampling station. We also indicate the length in months of anoxia periods.

Tableau 1. Valeurs minimum et maximum de la température et de l'oxygène dissous de l'eau proche du sédiment dans les stations étudiées. Nous indiquons aussi le nombre de mois que dure l'anoxie.

\begin{tabular}{|c|c|c|c|c|c|c|c|c|}
\hline Basin-Depth & $1-5 \mathrm{~m}$ & $1-12 \mathrm{~m}$ & $1-20 \mathrm{~m}$ & $11-20 \mathrm{~m}$ & $111-20 \mathrm{~m}$ & III-5 m & IV-7 m & IV-13 m \\
\hline $\begin{array}{l}\text { Temperature range }\left({ }^{\circ} \mathrm{C}\right) \\
\text { Oxygen range }(\mathrm{mg} / \mathrm{l}) \\
\text { Months with oxygen }<3 \mathrm{mg} / \mathrm{l}\end{array}$ & $\begin{array}{c}8.6-25 \\
5.5-11.2 \\
0\end{array}$ & $\begin{array}{c}8.6-18 \\
0.8-9.9 \\
2 \\
\text { (Sep-Oct) }\end{array}$ & $\begin{array}{c}8.6-17.9 \\
0.4-9.8 \\
2 \\
\text { (Sep-Oct) }\end{array}$ & $\begin{array}{c}8.2-18 \\
0.23-10.2 \\
3 \\
\text { (Aug-Oct) }\end{array}$ & $\begin{array}{c}9.7-14 \\
0.06-2.8 \\
12 \\
\text { (Jan-Dec) }\end{array}$ & $\begin{array}{c}8.3-25.5 \\
5.9-10.8 \\
0\end{array}$ & $\begin{array}{c}8-22.5 \\
7.4-10.5 \\
0\end{array}$ & $\begin{array}{c}\text { 8-16.2 } \\
0.05-9.87 \\
5 \\
\text { (Jul-Nov) }\end{array}$ \\
\hline Months with oxygen $<1 \mathrm{mg} / \mathrm{l}$ & 0 & $\left(\begin{array}{c}1 \\
\text { Oct }\end{array}\right.$ & $\begin{array}{c}1 \\
(O c t)\end{array}$ & $\begin{array}{c}1 \\
(O c t)\end{array}$ & $\begin{array}{c}12 \\
\text { (Jan-Dec) }\end{array}$ & 0 & 0 & $\begin{array}{c}4 \\
\text { (Aug-Nov) }\end{array}$ \\
\hline
\end{tabular}


This is an oligotrophic lake, with a cosmopolitan phyto- and zooplankton composition. However, these data do not agree with the profundal benthic fauna, which reflect mesotrophic conditions, due mainly to the lack of oxygen near the sediment during the stratification period (Rieradevall \& Prat 1989, 1991).

\section{Methods}

Sediment samples were taken monthly, between. December 1986 to December 1987, with a modified $400 \mathrm{~cm}^{2}$ Ekman grab. Three replicates were filtered through $150 \mu \mathrm{m}$ mesh, at eight sampling stations situated in different basins (I, II, III and IV) (Fig. 1) at 5, 7, 12 and $20 \mathrm{~m}$ depth, i.e., at sublittoral and profundal zone of the lake. Totally 254 samples were studied. Organisms were sorted alive with the flotation method (Anderson 1959), fixed with formalin (4 \%) until counting under a stereoscopic microscope at 10 magnifications and stored in $70 \%$ ethanol in plastic vials. Finally, after identification, water mite individuals were permanently stored in Koenike's fluid. Water mite nomenclature follows Viets (1987).

\section{Results}

Water mites represent only $0.08-0.39 \%$ of the total macrobenthic fauna of the whole sublittoral and profundal zone of the lake, with mean annual densities of 25 individuals per square meter. Four species were present in the sublittoral area of the lake : Neumania deltoides (Piersig, 1894), Neumania imitata Koenike, 1908, Unionicola crassipes (Müller, 1776) and Arrenurus sinuator (Müller, 1776).
From the eigth sampling stations studied, water mites appeared only in four of them (Table 2) and the maximum depth reached was $12 \mathrm{~m}$, where problems of lack of oxygen begins (Table 1) (Rieradevall 1991).

Neumania deltoides is the most widely distributed species, from 5 to $12 \mathrm{~m}$ depth (Table 2) and the most abundant. In basin $\mathrm{I}$ at $5 \mathrm{~m}$ depth this species was found more frequently and with the greatest densities, with maxima in May $\left(41.6 \mathrm{ind} / \mathrm{m}^{2}\right.$ ) (Fig. 2). Adults were present in spring and autumn, while nymphs appeared in August (basin I, $5 \mathrm{~m}$ ) or July (basin I, $12 \mathrm{~m}$ ).

Arrenurus sinuator individuals were found only at the shallow stations, at $5 \mathrm{~m}$ depth in basin $\mathrm{I}$, with low densities $\left(8 \mathrm{ind} / \mathrm{m}^{2}\right)$. Females were present in spring (March to Abril) and autumn (November), while nymphs appeared in mid and late summer.

The latter two species appeared only scarcely. $N$. imitata were present on one occasion and in a single sampling station. Unionicola crassipes females were found in February and August in basin IV at $7 \mathrm{~m}$ and in basin $\mathrm{I}$ at $5 \mathrm{~m}$ respectively; densities varied between 8 to $25 \mathrm{ind} / \mathrm{m}^{2}$. This species is normally found more frequently in pelagic samples, due to its long extremities and its swimming ability, which allows it to prey on planktonic copepoda and cladocera populations ; but adults can also prey on benthonic ephemeroptera and chironomid larvae (Proctor \& Pritchard 1989).

\section{Discussion}

The vertical distribution of water mites in lakes reveals a decrease in both the number of individuals

Table 2. Specific composition, number of species and mean annual densities (ind $/ \mathrm{m}^{2}$ ) of water mites at each sampling station in lake Banyoles.

Tableau 2. Composition spécifique, nombre d'espèces et densités moyennes annuelles (ind $\left./ \mathrm{m}^{2}\right)$ des Hydracariens dans chaque station du lac de Banyoles.

\begin{tabular}{lcccccccc}
\hline Basin & $I$ & 1 & $I$ & II & III & III & IV & IV \\
Depth (m) & 5 & 12 & 20 & 20 & 5 & 20 & 7 & 13 \\
\hline Arrenurus sinuator & + & - & - & - & - & - & - & - \\
Neumania deltoides & + & + & - & - & - & - & + & - \\
$\begin{array}{l}\text { Neumania imitata } \\
\text { Unionicola crassipes }\end{array}$ & - & - & - & - & + & - & - & - \\
& - & - & - & - & - & + & - \\
$\begin{array}{l}\text { Species number } \\
\text { Mean annual densities }\end{array}$ & 17 & 1 & 0 & 0 & 1 & 0 & 2 & 0 \\
\hline
\end{tabular}




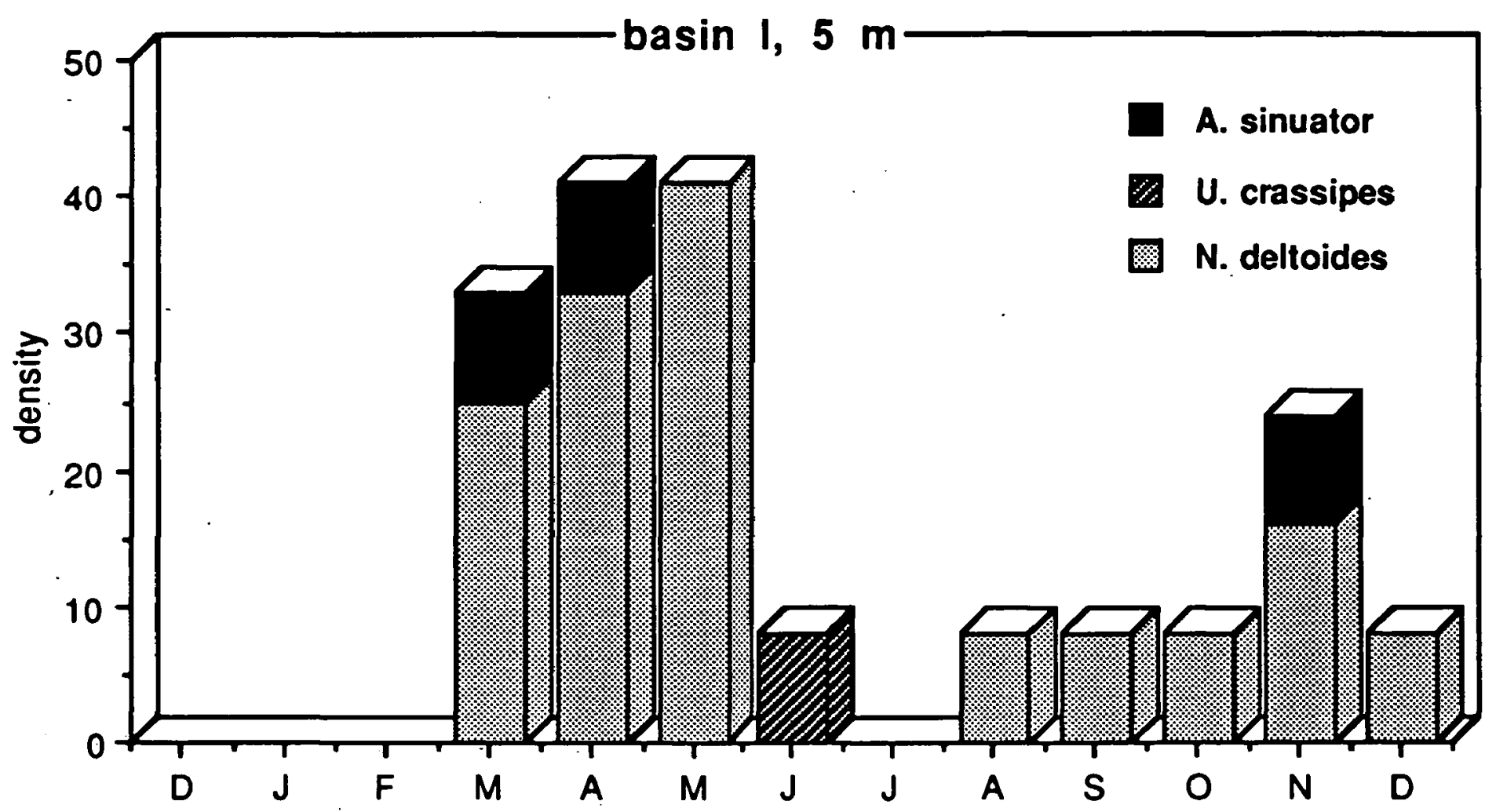

Fig. 2. Density (ind $/ \mathrm{m}^{2}$ ) variation from December 1986 to December 1987 of water mite species in the sublittoral zone of lake Banyoles (basin $\mathrm{I}$ at $5 \mathrm{~m}$ ).

Fig. 2. Variation de la densité des acarides, exprimée en ind $/ \mathrm{m}^{2}$, entre Décembre 1986 et Décembre 1987 dans la zone sublittorale du Lac de Banyoles (bassin I à $5 \mathrm{~m}$ ).

and the number of species with depth (Pieczinsky 1976), as occurs in lake Banyoles (Table 2). Our samples were all taken in mud substrata and this kind of habitat normally has lower diversity than the areas with macrophytic vegetation (Pieczinsky, loc. cit.), where a greater number of microhabitats, substrata and hides from predators are possible. This could explain the low species richness in the uniform mud surface habitats sampled in lake Banyoles.

Low abundances of water mites in deep zones, and other predators, have been attributed to their low resistence to anoxic waters (Jonasson 1978). Meyer \& Schwoerbel (1981), in their study of Mindelsee water mites, found that oxygen levels play a significant role in water mite distribution. However, for Viets (1924) and Pieczinsky (1976) this factor does not play an important role in these distribution. Even though, in our study, when anoxic conditions remain so long no water mite communities can be established, whereas, in shorter periods, oxygen conditions do not seem to be the key factor in the distribution of water mites in lake Banyoles.
In Banyoles, the most frequent and abundant species was Neumania deltoides. Several authors have found a good correlation between depth and $N$. deltoides densities, these being more abundant in sublittoral than in littoral zones (Pieczinsky 1964, Meyer \& Schwoerbel 1981, Bägge 1986).

Food availability and the presence of potential hosts have been described as key factors in the maintenance of water mite populations (Mitchell 1964, Pieczinsky 1976, Davids et al. 1981). In Table 3, a good relationship between water mites and their potential hosts and preys is shown. The three main species present in the mud substrates in lake Banyoles, ( $N$. deltoides, $U$. crassipes and $A$. sinuator) eat Copepoda, Cladocera, Nematoda, Ephemeroptera and, specially the former one, Chironomidae (Mitchell 1964, Proctor \& Pritchard 1989). Also, Chironomids are one of the main host of this water mite species.

On the other hand, several potential water mite predators have been cited in the literature, such as Zygoptera larvae, Notonectidae, Corixidae, Chaoboridae and fishes (Eriksson et al. 1980, 
Table 3. Mean annual densities (ind $/ \mathrm{m}^{2}$ ) of water mites and their potential preys, hosts and predators in the benthos of lake Banyoles. Tableau 3. Densités moyennes annuelles des Hydracariens (ind $/ \mathrm{m}^{2}$ ) et de leurs proies, hôtes et prédateurs potentiels dans le benthos du lac de Banyoles.

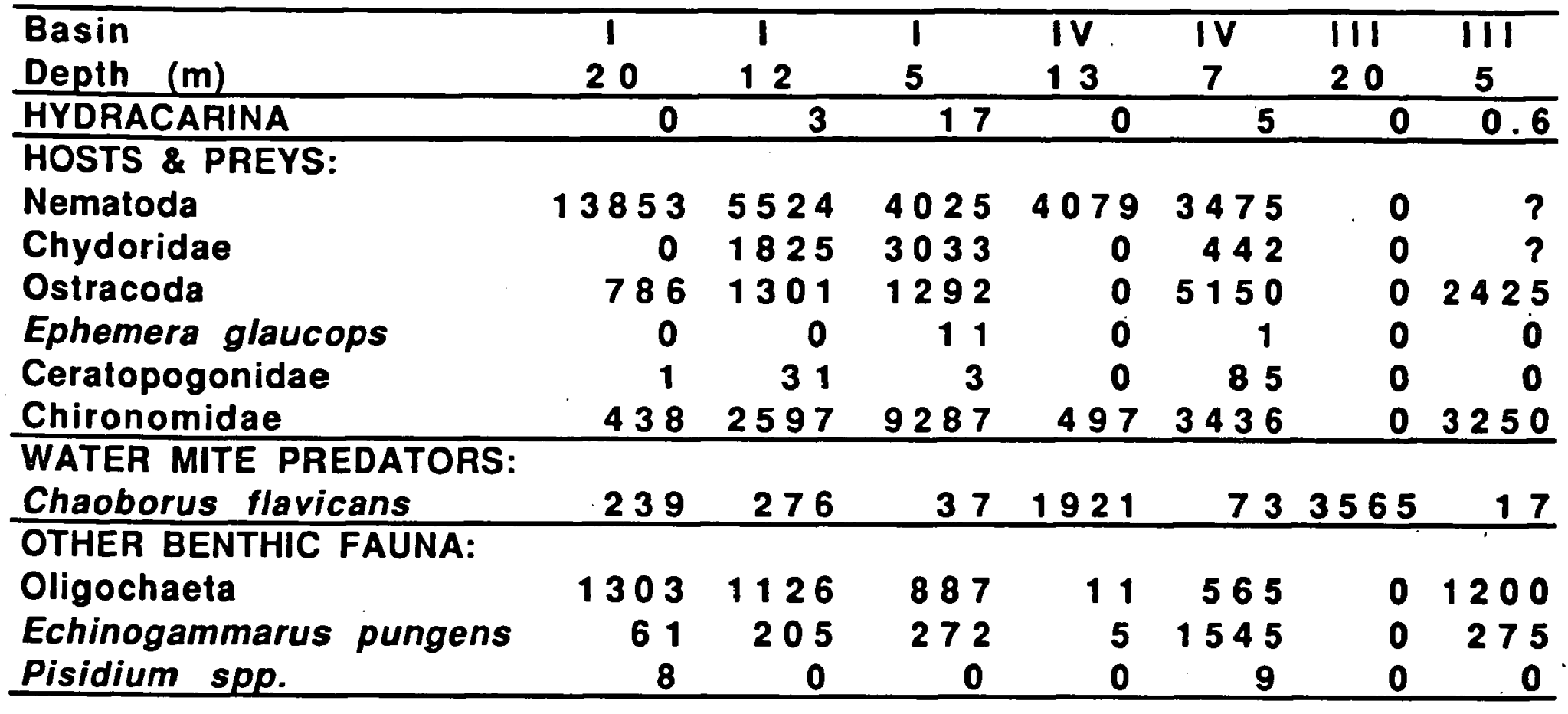

Gledhill 1985, Bägge 1986, Ten Winkel 1987). In the sublittoral and deep zones of lake Banyoles this role may be played for Chaoborus flavicans and several fish species (Cyprinus carpio, Scardinius erytrophthalmus) (Table 3).

Finally, the special and sporadic presence of $\mathrm{Neu}$ mania imitata in the lake can be interpretated considering this species as an immigrant but not as a real resident in the sublittoral zone according with Mitchell (1964). As this species has not been found in the littoral zone, we suppose that its life cycle is not completed in the lake but in another water body, irrespective of its distance from the lake Banyoles. This is the first time that this species has been reported in the iberian peninsula.

\section{Aknowledgements}

The authors are grateful to Dr. N. Prat for his comments on the manuscript and Mr. R. Rycroft for correcting english. Funds for the research came from Caycit PR84-0747 project, and a Caixa de Barcelona personal grant to one of the authors.

\section{References}

Anderson R.O. 1959. - A modified flotation technique for sorting bottom fauna samples. Limnol. Oceanogr. 4 : 223-225.
Bägge P. 1986. - Phenology and bathygraphic occurrence of water mites (Acari, Hydrachnellae) in some brown and clear lakes of southeastern Finland. Memo. Soc. Fauna Flora Fenn. $62: 17-25$.

Böttger K. 1970. - Die Ernährungsweise der Wassermilben (Hydrachnellae, Acari). Int. Revue ges. Hydrobiol. 55 (6) : 895-912.

Böttger K. 1976. - Types of parasitism by larvae of water mites (Acari : Hydrachnellae). Freshwat. Biol. 6 : 497-500.

Davids C., Heijnis C.F. \& Weekenstroo J.E. 1981. - Habitat differentiation and feeding strategies in water mites in Lake Maarsseveen I. Hydrobiol. Bull. 15 (1/2) : 87-91.

Eriksson M., Henrikson L. \& Oscarson H.G. 1980. - Predatorprey relatonships among water-mites (Hydracarina) and other freshwater organisms. Arch. Hydrobiol. 88 (2) : 146-154.

Gledhill T. 1985. - Water mites predators and parasites. Freshwater Biol. Assoc. Ambleside, 53 Annual report : 45-59.

Jonasson P.M. 1978. - Zoobenthos of lakes. Verh. Internat. Verein. Limnol. 20 : 13-37.

Meyer E. \& Schwoerbel J. 1981. - Untersuchungen zur Phänologie der Wassermilben (Hydracarina) des Mindelsees. Arch. Hydrobiol. Suppl, 59 (2/3) : 192-251.

Mitchell R. 1964. - A study of sympatry in the water mite genus Arrenurus (fam. Arrenuridae). Ecology. 45 (3) : 546-558.

Pieczynski E. 1964. - Analysis of numbers, activity and distribution of water mites (Hydracarina) and of some other aquatic invertebrates in the lake littoral and sublittoral. Ekol. pol., (A) XII (35) : 691-733.

Pieczynski E. 1976. - Ecology of water mites (Hydracarina) in lakes. Pol. Ecol. Stud., 2 (3) : 5-54.

Planas M.D. 1973. - Composición, ciclo y productividad del fitoplancton del lago de Banyoles. Oecol. Aquatica. 1 : 3-106. 
Prasad V. \& Cook O. 1972. - The taxonomy of water mite larvae. Mem. Amer. Entom. Inst. $18: 1-325$.

Proctor H. \& Pritchard G. 1989. - Neglected predators : water mites (Acari : Parasitengona : Hydrachnellae) in freshwater communities. J. N. Am. Benthol. Soc. 8 (1) : 100-111.

Rieradevall M. 1991. - Ecology and production of benthos in lake Banyoles. Ph. D. thesis dissertation. University of Barcelona. 242 p.

Rieradevall M. \& Prat N. 1989. - Chironomidae of profundal samples of Banyoles lake (NE Spain). Acta Biologica Debrecina. Suppl. Oecol. Hung. 3 : 267-274.

Rieradevall M. \& Prat N. 1991. - Benthos of Banyoles lake (NE Spain). Verh. Internat. Verein. Limnol. 24 : 1020-1023.
Viets K. 1924, - Die Hydracarinen der norddeutschen, besonders der holsteinischen Seen. Arch. Hydrobiol. Suppl. IV : 71-179.

Viets K.O. 1979. - Wassermilben (Hydrachnellae, Acari) aus dem Littoral des Bodensees. Arch. Hydrobiol. 87 (1) : 84-94.

Viets K.O. 1987. - Die Milben des Subwassers (Hydrachnellae und Halacaridae (part.) Acari 2: Katalog, Sonderbd. Naturwiss. ver. Hamburg, 8, Verlag Paul Parey, Hamburg und Berlin. 983 p.

Ten Winkel E.H. 1987. - Chironomid larvae and their foodweb relations in the littoral zone of lake Maarsseveen. Unpublished Ph. D. Thesis. Dep. Aquatic Ecology. University of Amsterdam, The Netherlands: 145 p. 